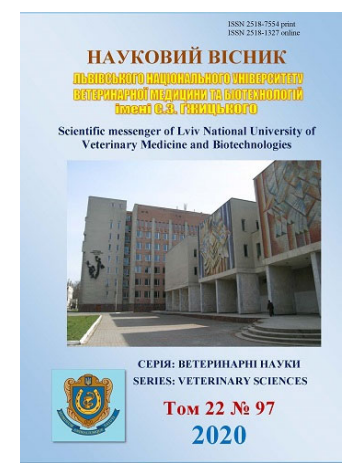

\author{
Науковий вісник Дьвівського національного університету \\ ветеринарної медицини та біотехнологій імені С.3. Гжицького. \\ Серія: Ветеринарні науки \\ Scientific Messenger of Lviv National University \\ of Veterinary Medicine and Biotechnologies. \\ Series: Veterinary sciences
}

UDC 615.33.636.09

\title{
Investigation of the antimicrobial activity of danofoloxacin against bacteria pathogens in goats
}

\author{
T. I. Stetsko, Ya. M. Liubenko, V. N. Padovskyi, L. L. Ostrovska, O. Yo. Kalinina, O. Z. Balyan \\ State Scientific-Research Control Institute of Veterinary Medicinal Products and Feed Additives, Lviv, Ukraine
}

Article info

Received 30.01.2020

Received in revised form 02.03 .2020

Accepted 03.03.2020

State Scientific-Research Control Institute of Veterinary Medicinal

Products and Feed Additives,

Donetska Str., 11, Lviv,

79019, Ukraine.

Tel.: +38-067-252-98-29

E-mail: stetskot@ukr.net
Stetsko, T. I., Liubenko, Ya. M., Padovskyi, V. N., Ostrovska, L. L., Kalinina, O. Yo., \& Balyan, $O$. Z. (2020). Investigation of the antimicrobial activity of danofoloxacin against bacteria pathogens in goats. Scientific Messenger of Lviv National University of Veterinary Medicine and Biotechnologies. Series: Veterinary sciences, 22(97), 74-78. doi: 10.32718/nvlvet9713

Fluoroquinolones are critical antimicrobials for both human and veterinary medicine. Due to their unique mechanism of antimicrobial action and good pharmacokinetic properties, they are often the first choice drugs in the treatment of bacterial infections in animals. The purpose of the investigation was to study the antimicrobial activity of a third-generation fluoroquinolone antibiotic of danofloxacin against bacteria, pathogens of respiratory and intestinal infection in goats. The samples of the nasal outflows (respiratory infection) and fecal masses (intestinal infection) were collected from clinically ill goats for microbiological studies. The sensitivity test of the microflora of the biomaterial, carried out by the disco-diffusion method, showed that the microorganisms of all the samples were sensitive to danofloxacin. Bacteria Streptococcus pneumonia $(n=10)$, Staphylococcus aureus $(n=4)$ and Escherichia coli $(n=2)$ were isolated and identified from nasal exudate samples $(n=10)$. Pathogenic strains of Escherichia coli were isolated from all faecal samples $(n=12)$. The degree of bacteriostatic activity of danofloxacin was determined by establishing its minimum inhibitory concentration (MIC) for bacterial isolates by sequential dilutions in a liquid nutrient medium. The average MIC of danofloxacin for Streptococcus pneumoniae isolates was $0.26 \pm 0.13 \mu \mathrm{g} / \mathrm{ml}$ and for Staphylococcus aureus isolates $-0.25 \pm 0.075 \mu \mathrm{g} / \mathrm{ml}$. For Escherichia coli strains isolated from faeces of goats suffering from coli infection, the average MIC of danofloxacin was $0.38 \pm 0.12 \mu \mathrm{g} / \mathrm{ml}$ (range 0.2 to $0.8 \mu \mathrm{g} / \mathrm{ml}$ ). Antimicrobial sensitivity testing have shown a high level of bacteriostatic activity of danofloxacin against bacteria, pathogens of respiratory and intestinal infections in goats. This may be the argument for the use of danofloxacin-based chemotherapeutic agents in the treatment of bacterial infections in goats, especially for the empirical approach to therapy.

Key words: fluoroquinolones, danofloxacin, goats, respiratory and intestinal infections, bacteria, Streptococcus pneumoniae, Staphylococcus aureus, Escherichia coli, sensitivity of microorganisms, minimum inhibitory concentration.

\section{Дослідження антимікробної активності данофлоксацину проти збудників бактеріальних інфекцій у кіз}

\author{
Т. І. Стецько, Я. М. Любенко, В. Н. Падовський, Л. Л. Островська, О. Й. Калініна, О. 3. Балян
}

Державний науково-дослідний контрольний інститут ветеринарних препаратів та кормових добавок, м. Львів, Україна

\footnotetext{
Фторхінолони є критично важливими антимікробними речовинами як для гуманної, так і для ветеринарної медицини. Завдяки унікальному механізму антимікробної дї та добрим фармакокінетичним властивостям, вони часто служать препаратами першого вибору при лікуванні бактеріальних інфекиій у тварин. Метою дослідження було вивчення антимікробної активності фторхінолонового антибіотика третього покоління данофлоксацину щзодо бактерій, збудників респіраторної та кишкової інфекції у кіз. Для мікробіологічних досліджень від клінічно хворих кіз відбирали зразки носових виділень (респіраторна інфекиія) і калових
} 
мас (кишкова інфекиія). Тест на чутливість мікрофлори біоматеріалу, проведений диско-дифузійним методом, показав, щзо мікроорганізми усіх зразків були чутливими до данофлоксацину. Зі зразків носового ексудату (n=10) були виділені та ідентифіковані бактерії Streptococcus pneumoniae $(n=10)$, Staphylococcus aureus $(n=4)$ i Escherichia coli $(n=2)$. 3 усіх зразків калових мас $(n=12)$ були виділені патогенні штами Escherichia coli. Ступінь бактеріостатичної активності данофлоксацину визначали иляхом встановлення його мінімальної інгібуючої концентрації (МІК) для бактерій-ізолятів методом послідовних розведень у рідкому поживному середовищі. Середнє значення МІК данофлоксацину для ізолятів Streptocoсcиs рпеитопіае становило 0,26 \pm 0,13 мкг/мл, а для ізолятів Staphylococcus aureus - 0,25 0,075 мкг/мл. Для штамів Escherichia coli, виділених з фекалій кіз, хворих на коліінфекцію, середнє значення МІК данофлоксацину становило 0,38 0,12 мкг/мл (діапазон від 0,2 до 0,8 мкг/мл). Дослідження антимікробної чутливості показало високий рівень бактеріостатичної активності данофлоксацину щзодо бактерій, збудників респіраторної та кишкової інфекиій у кіз. Це може служити підставою для застосування хіміотерапевтичних засобів на основі данофлоксацину в лікуванні бактеріальних інфекцій у кіз, особливо при емпіричному підході до терапії.

Ключові слова: фторхінолони, данофлоксацин, кози, респіраторні та кишкові інфекиії, бактерї, Streptocoсcиs рпеитопіае, Staphylococcus aureus, Escherichia coli, чутливість мікроорганізмів, мінімальна інгібуюча конщентрація.

\section{Вступ}

Кози, як і інші види сільськогосподарських тварин, схильні до інфекційних хвороб. Інфекції можуть мати різну етіологію - вірусну, бактеріальну, грибкову. Бактеріальні інфекції є одними 3 найпоширеніших захворювань кіз (Duhamel et al., 1992; Oros et al., 1997; Berge et al., 2006). На сьогодні антибактеріальні препарати залишаються основними засобами їхнього лікування. Вибір ефективного антибіотика часто ускладнюється наявністю антибіотикорезистентних штамів мікроорганізмів (Paphitou, 2013; Clifford et al., 2018). Тому ефективність лікування бактеріальних хвороб у значній мірі залежить від хіміотерапевтичного засобу, активно діюча речовина якого володіла б високою біологічною активністю щодо мікроорганізмів, збудників інфекцій (Boothe, 2006; Stetsko, 2008).

Антибіотики групи фторхінолонів $є$ одними 3 найефективніших засобів хіміотерапії бактеріальних інфекцій у тварин. Їхня ефективність пов'язана насамперед з унікальним механізмом антимікробної дії. Фторхінолони діють бактерицидно, блокуючи активність ферментів ДНК-гіраза і топоізомераза IV, які забезпечують суперспіралізацію ДНК, що призводить до загибелі мікробної клітини (Smith \& Lewin, 1988; Hooper \& Wolfson, 1993). Фторхінолони мають добрі фармакокінетичні властивості. Вони характеризуються високим рівнем біодоступності, великим об'ємом розподілу в макроорганізмі, створюючи високі концентрації у більшості тканин та рідин організму і проникаючи всередину клітин, тривалим періодом напіввиведення (Yakovlev, 1993). Фторхінолони є антибіотиками широкого спектру дії, що належать до критично важливих антимікробних препаратів як для гуманної, так і для ветеринарної медицини (Yakovlev, 1999; Resolution OIE No. XXVIII, 2007; WHO, 2011).

Ще одною особливістю фторхінолонів $\epsilon$ те, що стійкість мікроорганізмів до цього класу антибіотиків виникає внаслідок генних мутацій у хромосомах бактерій, рідше поширюючись через плазміди, що значно сповільнює появу антибіотикорезистентних штамів. Відсутні дані щодо ензимної інактивації фторхінолонів бактеріями, для антибіотиків цієї групи не характерна перехресна резистентність 3 іншими класами антибіотиків (Stetsko, 2005).

Метою роботи було вивчити активність антимікробного препарату Данофлокс, розчину для ін'єкцій, виробництва ПАТ “Галичфарм” (Україна), на основі фторхінолонового антибіотика третього покоління данофлоксацину стосовно до мікроорганізмів, збудників бактеріальних інфекцій у кіз.

\section{Матеріал і методи досліджень}

Дослідження проводили на базі одного з фермерських господарств Львівської області, що спеціалізувалося на вирощуванні кіз молочного напрямку. Суб'єктами дослідження був молодняк кіз 3 клінічними ознаками гострої респіраторної (пневмонія) та кишкової (ентерит) інфекції. Діагноз ставили на основі даних анамнезу, клінічних симптомів захворювання та результатів мікробіологічного дослідження.

Для мікробіологічних досліджень від хворих тварин відбирали зразки носових виділень (респіраторна інфекція) та калових мас (кишкова інфекція). Чутливість до данофлоксацину мікрофлори біоматеріалу встановлювали методом дифузії в агар з використанням паперових дисків 3 данофлоксацином. Інтерпретацію результатів тесту на чутливість проводили таким чином: діаметр затримки росту навколо диску 3 данофлоксацином: $\geq 21$ мм - мікрофлора чутлива; 2016 мм - помірно чутлива; $\leq 16$ мм - резистентна (National Committee for Clinical Laboratory Standards, 2004).

Виділення та ідентифікацію мікроорганізмів проводили за загальноприйнятими мікробіологічними методиками. Рівень бактеріостатичної активності препарату Данофлокс щодо збудників бактеріальних інфекцій кіз визначали шляхом встановлення мінімальної інгібуючої концентрації данофлоксацину (МIК) для бактерій-ізолятів методом серійних розведень у рідкому поживному середовищі (Yoshimura et al., 2002). Для цього були приготовлені розведення препарату Данофлокс 3 концентрацією діючої речовини у розчинах $50,25,12,5,6,2,3,1,1,6,0,8,0,4,0,2$, $0,1,0,05$ i 0,025 мкг/мл. Інтерпретацію отриманих значень МІК антибіотиків для бактерій-ізолятів проводили таким чином: $\leq 0,5$ мкг/мл - штам мікроорганізму чутливий; від 0,5 до 4,0 мкг/мл - помірно чутливий; $\geq 4$ мкг/мл - резистентний (National Committee for Clinical Laboratory Standards, 2004). 


\section{Результати та їх обговорення}

Результати тесту на чутливість мікрофлори носових виділень хворих на пневмонію кіз наведені у таблиці 1.

Отримані результати показали високий рівень чутливості мікрофлори носового ексудату кіз, хворих на пневмонію, до діючої речовини препарату Данофлокс. Середня величина діаметру зони затримки росту мікрофлори навколо диска 3 данофлоксацином становила $27,5 \pm 1,95$ мм.

3 усіх зразків носового ексудату $(\mathrm{n}=10)$ були виділені стрептококи (Streptococcus pneumoniae). 3 4 зразків біоматеріалу, окрім стрептококу, були виділенні стафілококи (Staphylococcus aureus), $з$ двох - кишкова паличка (Escherichia coli).

Отримані значення МІК данофлоксацину для ізолятів Streptococcus pneumoniae показані на рисунку 1.

За значеннями МІК до данофлоксацину чутливими були усі виділені штами стрептококу. Середнє зна- чення МІК данофлоксацину для ізолятів Streptococcus pneumoniae становило $0,26 \pm 0,13$ мкг/мл.

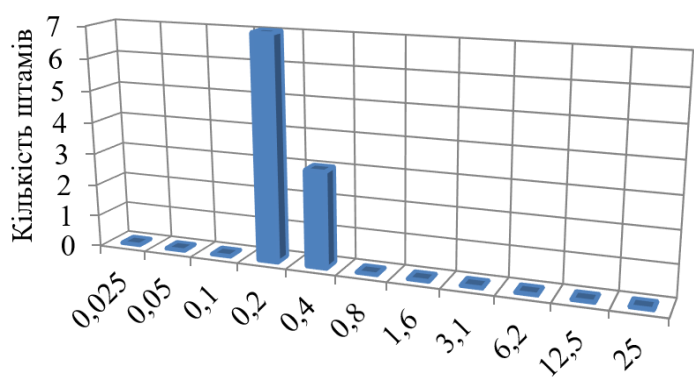

Мінімальна інгібуюча концентрація, мкг/мл

Рис. 1. МІК данофлоксацину для ізолятів Streptococcus pneumoniae (мкг/мл, $\mathrm{n}=10$ )

Результати визначення МІК данофлоксацину для ізолятів Staphylococcus aureus і Escherichia coli наведені у таблиці 2.

\section{Таблиця 1}

Чутливість мікрофлори носових виділень хворих на пневмонію кіз до данофлоксацину $(\mathrm{n}=10)$

\begin{tabular}{lcccccccccccc}
\hline \multicolumn{1}{c}{ Антибіотик } & \multicolumn{1}{c}{ Діаметр зон затримки росту, мм } \\
\cline { 2 - 9 } & 1 & 2 & 3 & 4 & 5 & 6 & 7 & 8 & 9 & 10 \\
\hline данофлоксацин & 30 & 29 & 26 & 30 & 28 & 25 & 25 & 27 & 26 & 29 \\
рівень чутливості & Ч & Ч & Ч & Ч & Ч & Ч & Ч & Ч & Ч & Ч \\
\hline
\end{tabular}

Примітка: "Ч”- мікрофлора чутлива

\section{Таблиця 2}

МІК данофлоксацину для ізолятів Staphylococcus aureus $(\mathrm{n}=4)$ i Escherichia coli $(\mathrm{n}=2)$

\begin{tabular}{|c|c|c|c|c|c|c|}
\hline \multirow{3}{*}{$\begin{array}{c}\text { Концентрація } \\
\text { антибіотика }\left(\text { мкг/ } \mathrm{cm}^{3}\right)\end{array}$} & \multicolumn{6}{|c|}{ Мікроорганізм } \\
\hline & \multicolumn{4}{|c|}{ Staphylococcus aureus } & \multicolumn{2}{|c|}{ Escherichia coli } \\
\hline & 1 & 2 & 3 & 4 & 1 & 2 \\
\hline 25 & - & - & - & - & - & - \\
\hline 12,5 & - & - & - & - & - & - \\
\hline 6,2 & - & - & - & - & - & - \\
\hline 3,1 & - & - & - & - & - & - \\
\hline 1,6 & - & - & - & - & - & - \\
\hline 0,8 & - & - & - & - & + & - \\
\hline 0,4 & - & - & - & - & + & - \\
\hline 0,2 & - & - & - & + & + & + \\
\hline 0,1 & + & + & + & + & + & + \\
\hline 0,05 & + & + & + & + & + & + \\
\hline 0,025 & + & + & + & + & + & + \\
\hline
\end{tabular}

Примітка: “_”- відсутність росту; “+”- наявність росту

За значеннями МІК усі виділені штами Staphylococcus aureus були чутливими до данофлоксацину. Середнє значення МІК антибіотика для ізолятів Staphylococcus aureus становило 0,25 \pm 0,075 мкг/мл. Один штам Escherichia coli був помірно чутливий
(МІК = 1,6 мкг/мг) до данофлоксацину, інший - чутливий (МІК $=0,4$ мкг/мл).

Результати тесту на чутливість мікрофлори калових мас до данофлоксацину, проведеного дискодифузійним методом, наведені у таблиці 2.

\section{Таблиця 2}

Чутливість мікрофлори калових мас хворих на ентерит кіз до данофлоксацину (n = 12)

\begin{tabular}{lcccccccccccccccc}
\hline \multicolumn{1}{c}{ Антибіотик } & \multicolumn{1}{c}{ Діаметр зон затримки росту, мм } \\
\cline { 2 - 9 } & 1 & 2 & 3 & 4 & 5 & 6 & 7 & 8 & 9 & 10 & 11 & 12 \\
\hline данофлоксацин & 25 & 26 & 25 & 29 & 23 & 28 & 26 & 23 & 25 & 27 & 25 & 26 \\
рівень чутливості & Ч & Ч & Ч & Ч & Ч & Ч & Ч & Ч & Ч & Ч & Ч & Ч \\
\hline
\end{tabular}

Примітка: "Ч” - мікрофлора чутлива 
За розмірами зон затримки росту до данофлоксацину виявилася чутливою мікрофлора усіх фекальних зразків (100\%). Середнє значення діаметру зони затримки росту мікроорганізмів навколо диску 3 данофлоксацином становило $25,7 \pm 1,33$ мм.

3 усіх зразків калових мас була виділена та іденфікована кишкова паличка (Escherichia coli). На основі отриманих результатів бактеріологічного дослідження був поставлений остаточний діагноз “колібактеріоз кіз".

Результати встановлення МІК данофлоксацину в препараті Данофлокс для ізолятів Escherichia coli показані на рис. 2.

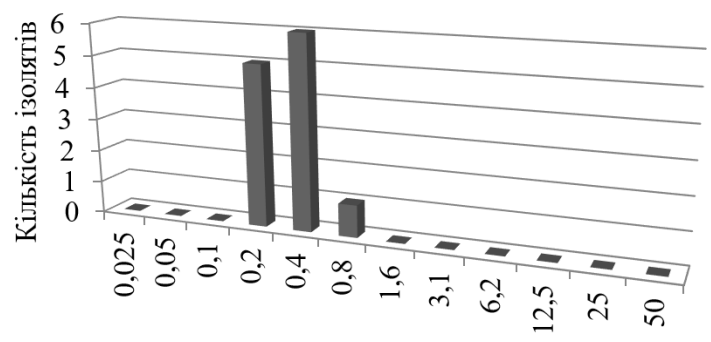

Мінімальна інгнібуюча концентрація, мкг/мл

Рис. 2. МІК данофлоксацину для ізолятів Escherichia coli $($ мкг/мл, $\mathrm{n}=12)$

За рівнем бактеріостатичної активності данофлоксацину 11 з 12 штамів кишкової палички виявилися чутливими до препарату $(91,7$ \%), і лише один штам помірно чутливим $(8,3$ \%). Середня величина МІК данофлоксацину для ізолятів Escherichia coli становила 0,38 \pm 0,12 мкг/мл (діапазон від 0,2 до 0,8 мкг/мл).

Отримані результати чутливості до данофлоксацину мікроорганізмів, збудників бактеріальних інфекцій у кіз, корелюють 3 даними, отриманими іншими дослідниками. Так, у дослідженнях Marín та ін. МІК данофлоксацину для 32 штамів Staphylococcus aureus, виділених 3 молока хворих на мастит кіз, становила в середньому 0,25 мкг/мл (Marín et al., 2010). Високий ступінь бактеріостатичної активності данофлоксацину підтверджений в дослідженнях Serrano-Rodríguez та iн., які вивчаючи чутливість до п'яти фторхінолонових антибіотиків 24 ізолятів Staphylococcus aureus, виділених від маститного молока кіз, отримали найнижчі значення МIC саме для данофлоксацину (Serrano-Rodríguez et al., 2017).

Є дані про високий рівень антимікробної активності данофлоксацину проти патогенних бактерій, виділених від інших видів продуктивних тварин (Cruz et al., 1997; Yoshimura et al., 2002; Zhao et al., 2005; Grobbel et al., 2007; Ozawa et al., 2010). Так, дослідження in vitro активності 16 антимікробних речовин показали найвищий рівень чутливості Actinobacillus pleuropneumoniae до данофлоксацину $\left(\mathrm{MIK}_{90}=0,05\right.$ мкг/мл) (Yoshimura et al., 2002). Середня величина $\mathrm{MIC}_{50}$ данофлоксацину для штамів Escherichia coli у випадках пташиного колибактеріозу становила 0,25 мкг/мл, тимчасом як норфлоксацину i офлоксацину - 0,5 мкг/мл (Ozawa et al., 2010).

\section{Висновки}

Бактеріальні інфекції є одними з найпоширеніших захворювань кіз. Успіх в їхньому лікуванні значною мірою залежить від вибору ефективних засобів етіотропної терапії, якими $\epsilon$ антибіотики. Ефективність антибіотикотерапії своєю чергою залежить від чутливості патогенних мікроорганізмів до діючої речовини чи речовин антимікробного препарату.

Дослідження in vitro чутливості бактерій-ізолятів до данофлоксацину показали високу ступінь біологічної активності цього фторхінолонового антибіотика проти збудників бактеріальних інфекцій дихальної та травної системи у кіз, що дає підставу стверджувати, що хіміотерапевтичний засіб ветеринарного призначення Данофлокс, розчин для ін'єкцій, виробництва ПАТ “Галичфарм", може служити препаратом першочергового вибору при лікуванні бактеріальних інфекцій у кіз.

Перспективи подальших досліджень. Науковопрактичне значення матимуть дослідження ефективності та безпечності при застосуванні препарату Данофлокс у лікуванні респіраторних та кишкових інфекцій бактеріальної етіології у кіз.

\section{References}

Berge, A. C., Sischo, W. M., \& Craigmill, A. L. (2006). Antimicrobial susceptibility patterns of respiratory tract pathogens from sheep and goats. J Am Vet Med Assoc, 229(8), 1279-1281. doi: 10.2460/javma.229.8.1279.

Boothe, D. M. (2006). Principles of antimicrobial therapy. Vet Clin North Am Small Anim Pract, 36(5), 1003-47. doi: 10.1016/j.cvsm.2006.07.002.

Clifford, K., Desai, D., Prazeres da Costa, C., Meyer, H., Klohe, K., Winkler, A. S., Rahman, T., Islame, T., \& Zamana, M. H. (2018). Antimicrobial resistance in livestock and poor quality veterinary medicines. Bull World Health Organ, 96(9), 662-664. doi: 10.2471/BLT.18.209585.

Cruz, A. D., Lopes C. A. D. M., Modolo, J. R., \& Gottschalk, A. F. (1997). Comparative "in vitro" study on the susceptibility and emergence of mutants resistant to danofloxacin and ciprofloxacin among Staphylococcus aureus isolated from bovine mastitis. Revista de Microbiologia. São Paulo, Soc Brasileira Microbiologia, 28(1), 61-64. http://hdl.handle.net/11449/32806.

Duhamel, G. E., Moxley, R. A., Maddox, C. W., \& Erickson, E. D. (1992). Enteric infection of a goat with enterohemorrhagic Escherichia coli. J Vet Diagn Invest, 4(2), 197-200. doi: 10.1177/104063879200400218.

Grobbel, M., Lubke-Becker, A., Wieler, L. H., Froyman, R., Friederichs, S., \& Filios, S. (2007). Comparative quantification of the in vitro activity of veterinary fluoroquinolones. Vet Microbiol, 124(1-2), 73-81. doi: 10.1016/j.vetmic.2007.03.017.

Hooper, D. C., \& Wolfson, J. S. (1993). Mechanism of quinolone action and bacterial killing. In "Quinolone 
Antimicrobial Agents". Amer. Soc. For Microbiol., Washington, 482-512.

Marín, P., Escudero, E., Fernández-Varón, E., Cárceles, C. M., Corrales, J.C., Gómez-Martín, A., Martínez, I. (2010). Short communication: Fluoroquinolone susceptibility of Staphylococcus aureus strains isolated from caprine clinical mastitis in southeast Spain. J Dairy Sci, 93(11), 5243-5245. doi: 10.3168/jds.2010-3345.

National Committee for Clinical Laboratory Standards. Performance standards for antimicrobial disk and dilution susceptibility tests for bacteria isolated from animals, informational supplement. (2004). NCCLS document M31-S1 (ISBN 1- 56238-534-8), p. 12.

Oros, J., Fernandez, A., Rodriguez, J. L., \& Poveda, J. B. (1997). Bacteria associated with enzootic pneumonia in goats. Journal of Veterinary Medicine series B, 44(110), 99-104. doi: 10.1111/j.1439-0450.1997.tb00955.x.

Ozawa, M., Baba, K., Shimizu, Y., \& Asai, T. (2010). Comparison of in vitro activities and pharmacokinetics/pharmacodynamics estimations of veterinary fluoroquinolones against avian pathogenic Escherichia coli isolates. Microb. Drug Resist, 16, 327-332. doi: 10.1089/mdr.2010.0024.

Paphitou, N. I. (2013). Antimicrobial resistance: action to combat the rising microbial challenges. Int $\mathrm{J}$ Antimicrob Agents, 42, 25-28. doi: 10.1016/j.ijantimicag.2013.04.007.

Resolution No. XXVIII. OIE LIST OF ANTIMICROBIAL AGENTS OF VETERINARY IMPORTANCE, adopted by International Committee of OIE on 24 May (2007).

Serrano-Rodríguez, J. M., Cárceles-García, C., CárcelesRodríguez, C.M., Gabarda, M.L., Serrano-Caballero, J. M., \& Fernández-Varón, E. (2017). Susceptibility and PK/PD relationships of Staphylococcus aureus strains from ovine and caprine with clinical mastitis against five veterinary fluoroquinolones. Vet Rec., 180(15), 376. doi: 10.1136/vr.103964.

Smith, L. T., \& Lewin, C. S. (1988). Chemistry and mechanisms of action of the quinolone antibacterials. In "Quinolones", Ed. Andriole V., Acaem. Press, 2382.

Stetsko, T. I. (2005). Rezystentnist do ftorkhinoloniv: pokhodzhennia, evoliutsiia, klinichne znachennia ta shliakhy podolannia. Biolohiia tvaryn, 7(1-2), 51-63 (in Ukrainian).

Stetsko, T. I. (2008). Zasady efektyvnoi antybiotykoterapii u veterynarnii medytsyni. Veterynarna biotekhnolohiia, 13(1), 194-200 (in Ukrainian).

WHO (2011). Critically Important Antimicrobials for human medicine publication. http:/www.who.int/ foodsafety/publications/antimicrobials-third/en.

Yakovlev, S. V. (1999). Mesto ftorhinolonov v lechenii bakterialnyih infektsiy. Antibiotiki i himioterapiya, 44(12), 27-30 (in Russian).

Yakovlev, V. P. (1993). Farmakokinetika ftorhinolonov. Antibiotiki i himioterapiya, 38(6), 66-78 (in Russian).

Yoshimura, H., Takagi, M., Ishimura, M., \& Endoh, Y. S. (2002). Comparative in vitro activity of 16 antimicrobial agents against Actinobacillus pleuropneumoniae. Vet Res Commun, 26(1), 11-19. doi: 10.1023/a:1013397419995.

Zhao, S., Maurer, J. J., Hubert, S., DeVillena, J. F., McDermott, P. F., Meng, J., Ayers, S., English, L., \& White, D. G. (2005). Antimicrobial susceptibility and molecular characterization of avian pathogenic Escherichia coli isolates. Vet. Microbiol., 107, 215224. doi: 10.1016/j.vetmic.2005.01.021. 